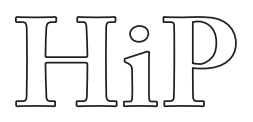

Historia i Polityka

$\mathrm{Nr} 13(20) / 2015$, ss. 159-169

ISSN 1899-5160

www.hip.umk.pl

DOI: http://dx.doi.org/10.12775/HiP.2015.010

Nataliia HOLUBIAK

Przykarpacki Narodowy Uniwersytet im. Wasyla Stefanyka, Iwano-Frankiwsk, Ukraina

\title{
Kształtowanie ukraińskiej polityki regionalnej: doświadczenie Polski a poszukiwanie własnych rozwiązań
}

\section{Regional Policy Formation of Ukraine: Polish Experience and the Search for Own Solutions}

\begin{abstract}
The characteristics and specifics of the regional policy of Ukraine and the Republic of Poland in the context of central and regional public authorities relations are researched in this article. The author reveals the positive aspects of Polish modernization transformations for the sake of their subsequent adaptation to the Ukrainian reality. The system of possible risks in pro-European implementation of decentralized management is shown. The author offers suggestions of reformatting regional policy in Ukraine.
\end{abstract}

Keywords: regional policy, mechanisms of regional development, decentralization, reforming Słowa kluczowe: polityka regionalna, mechanizmy rozwoju regionalnego, decentralizacji, reforma

Długoterminowy kurs Ukrainy na wejście do ogólnoeuropejskiej przestrzeni cywilizacyjnej określa strategię rozwoju systemu politycznego, która musi uwzględniać europejskie normy oraz standardy organizacji życia społecznego. Formowanie i konsekwentna realizacja polityki regionalnej, zgodnej z europejskimi standardami i ustawodawstwem Unii Europejskiej jest istotnym warunkiem wejścia Ukrainy do europejskiej przestrzeni i uzyskania przez Ukrainę członkostwa w UE. Ważnym kryterium jest także adaptacja tradycji demokratycznych do systemu zarządzania na poziomie regionalnym.

Ukraina musi więc czerpać z doświadczeń międzynarodowych, w tym doświadczeń Polski, która aktywnie działa w celu zbudowania społeczeństwa obywatelskiego, decentralizacji zarządzania, zwiększenia roli samorządów. Przez lata reform Polacy mają istotne osiągnięcia, które są efektem konsekwentnej polityki i gotowości do zmian. Ukraina powinna czerpać z tych wzorców - nie kopiując lecz adaptując reformy do ukraińskich realiów. Niestety państwo stoi przed nie- 
bezpieczeństwem i zagrożeniem integralności terytorialnej, a władze centralne są zdyskredytowane.

Aktualność podejmowanej problematyki wynika z kilku obiektywnych powodów: potrzeby określenia najbardziej efektywnych środków polityki regionalnej Ukrainy, które pomogą w uregulowaniu sporów między regionami i opracowaniu jej kierunków. Powstaje więc następujące pytanie: Co wpłynęło na kształt reformy polityki regionalnej w Polsce? Jakie problemy w tworzeniu skutecznego zarządzania regionalnego istnieją na Ukrainie? Jakie doświadczenia Polski na drodze integracji europejskiej mogą być przydatne dla Ukrainy? Co pomogłoby Ukrainie stworzyć własny scenariusz rozwoju? W kontekście tych pytań celem studium jest analiza i określenie skuteczności instrumentów rozwoju regionalnego oraz organizacja polityki regionalnej na Ukraine na podstawie polskich doświadczeń.

Badania tego problemu prowadzone są zarówno na Ukrainie jak i w Polsce. W polskiej literaturze można wyróżnić szereg prac, ukazujących proces tworzenia polityki regionalnej w Polsce w świetle problematyki integracji europejskiej. Warto wspomnieć o pracach: Witolda Morawskiego, Ireny Pietrzyk, Artura Adamczyka, Jana Borkowskiego, Artura Życkiego, Joanny Szafran, Alojzego Nowaka ${ }^{1}$ gdzie omówiono główne aspekty i wyzwania rozwoju regionalnego Polski. Osobno należy wymienić prace teoretyczne Antoniego Kuklińskiego, Michała Kuleszy, a także badania ukraińsko-polskiej grupy autorów prowadzonych przez Janusza Gonciarza: Zarządzanie regionalne i rozwój w Ukrainie i Ukraina na drodze do Unii Europejskiej. Vademecum, gdzie zaprezentowano polskie doświadczenia $\mathrm{w}$ kształtowaniu polityki rozwoju regionalnego ${ }^{2}$. Wśród ukraińskich badaczy warto wyróżnić Galinę Zeleńko, Sergeia Bajraka, Olega Bilańskyjego, Sergeia Boczarowa, Walentyna Malynowskiego, Natalię Szportjuk³ J Jednak stopień opracowa-

${ }^{1}$ W. Morawski, Zmiana instytucjonalna: spoteczeństwo, gospodarka, polityka, Warszawa 1998, s. 10-51; I. Pietrzyk, Polityka regionalna Unii Europejskiej i regiony w pañstwach członkowskich, Warszawa 2004, s. 325; Regionalizm, polityka regionalna i Fundusze Strukturalne w Unii Europejskiej, red. A. Adamczyk, J. Borkowski, Warszawa 2005, s. 365; A. Życki, Europejska polityka regionalna, Piła 2010, s. 80-91; J. Szafran, Implementacja unijnej polityki regionalnej w Polsce, Lublin 2010, s. 56-128; А. Новак, Європейська інтегращія. Шанси для Польщі - досвід дяя України, Аьвів 2006, s. 192.

${ }^{2}$ Dilemmas of Regional Policies in Eastern and Central Europe, red. G. Gorzelak, A. Kukliński, Warszawa 1992, s. 8-39; M. Kulesza, Methods and Techniques of Managing Decentralization Reforms in the CEE Countries: The Polish Experience, [w:] Mastering Decentralization and Public Administration Reforms in Central and Eastern Europe, red. G. Peteri, Budapest 2002, s. 189-214; Самоврядування та територіальна організачія влади в Польщі, red. Я. Гонцяжа, Київ 2001, s. 183.

${ }^{3}$ Г. Зеленько, „Навздогінна модернізачія”: досвід Польщі та України, Київ 2003, s. 215; С. Байрак, Місцеве самоврядування Республіки Польща: особливості становлення та заса- 
nia tej problematyki nie jest wystarczający, ponieważ brak całościowej analizy porównawczej reformy polityki regionalnej w kontekście Ukrainy i Polski.

Warto wziąć pod uwagę, że każde państwo formuje własną politykę regionalną, na podstawie poziomu rozwoju społeczno-gospodarczego i priorytetów narodowych, a na poziomie regionalnym - potencjału regionów, różnic terytorialnych, społeczno-kulturalnych, osobliwości problemów regionalnych, stopnia decentralizacji zarządzania państwowego i poziomu autonomii regionów.

Należy pamiętać, że Polska i Ukraina - to dwa państwa postsocjalistyczne, które posiadały nieomal jednakowe pozycje startowe na początku zmian transformacyjnych, bardzo podobne struktury gospodarki, podobną złożoną sytuację geopolityczną i spolaryzowany system polityczny. Przez dłuższy czas szły one różnymi drogami, więc ciekawe może okazać się ich porównanie. Pozwoli to na ocenę skuteczności realizacji polityki regionalnej i rozwoju regionalnego ${ }^{4}$.

Warto zauważyć, że reforma polityki regionalnej w Polsce była spowodowana celami strategicznymi państwa. Po pierwsze, potrzebą wprowadzenia decentralizacji, rozwojem społeczeństwa obywatelskiego, ograniczeniami wpływu państwa w sprawy lokalne (szczególnie w finanse). Po drugie, stworzeniem nowego modelu zarządzania regionalnego, zgodnie z wymogami UE.

Polska wykazała się racjonalnym podejściem do podziału uprawnień i kompetencji między trzema poziomami samorządu: gminą, powiatem i województwem. Wynikiem tych zmian było stworzenie państwa nowego typu, które służy swoim obywatelom i opierając się na instytucjach samorządowych i społeczeństwie obywatelskim, daje możliwość tworzenia i kontroli władz publicznych. Polskie doświadczenia ukazują, że stworzenie skutecznego zarządzania bez decentralizacji we współczesnej Europie jest niemożliwe. Oznacza to, że ogólne zasady skutecznej reformy administracyjnej i polityki regionalnej w każdym kraju regionu będą niemal identyczne.

ди функціонування, Studia Politologica Ucraino-Polona 2013, nr 3, s. 255-262; О. Бікянський, Адміністративно-територіальна реформа в Республічі Польща: досвід для Украйни (1998-1999 pр.), Україна-Європа-Світ: творимо історію разом 2008, nr 9, s. 146-153; С. Бочаров, Адміністративна реформа в Польщі як крокдо інтегращї в Європейський Союз, СхіА 2009, nr 4(95), s. 12-19; В. Малиновський, Уроки польської адміністративно-територіальної реформи для України, [w:] Державне та мунічипальне управління в умовах політико-адміністративної реформи, Ауцьк 2007, s. 15-18; Н. Шпортюк, Адміністративно-територіальна реформа в Польщі: досвід для України, Аержавне управління та місцеве самоврядування 2011, nr 2, s. $48-52$.

${ }^{4}$ В. Марчук, Суверенність та начіональні інтереси в $6 С$ : досвід Польщі для Украйни, Вісник Прикарпатського університету, Політологія 2014, nr 8, s. 53. 
Jednak jednym z głównych czynników polskiego sukcesu jest jedność Polaków jako zintegrowanego spójnego narodu, który wyciągnął właściwe wnioski z własnych (często bardzo bolesnych) doświadczeń historycznych i osiągnął zgodę społeczną w podejściu do rozwiązywania podstawowych problemów państwowych i bezpieczeństwa narodowego.

Warto zwrócić uwagę na czynniki, które przyczyniają się do przyspieszenia procesu reform - a mianowicie: silna wola polityczna liderów i przywódców państwa, chęć przeprowadzenia fundamentalnych zmian, wiedza ekspertów na temat określonych celów i sposobów ich osiągania, szkolenia zawodowe kadr, wsparcie publiczne. Konsolidacja wysiłków instytucji państwowych i społecznych doprowadzić może do pozytywnego wyniku reform i wprowadzenia efektywnego systemu władz publicznych'5.

Analizując zagadnienie polityki regionalnej należy uwzględnić fakt, że w Ukrainie przez to, że należała ona przez długi czas do Imperium Rosyjskiego, a potem - do ZSRR, nie było konsolidacji społeczeństwa wokół krajowych elit, nie były wypracowane mechanizmy samorozwoju. Wprowadzane reformy były odgórne, co doprowadziło do wyobcowania społeczeństwa oraz opozycji.

Obecnie kluczowe znaczenie mają następujące zagrożenia dla rozwoju regionalnego w Ukrainie: zaostrzenie „inności” regionalnej oraz regionalizmu politycznego, naruszenie skutecznej współpracy na płaszczyźnie „centrum - regiony” i „region - region"; obecność asymetrii regionalnej w projektach budżetowych państwa, niedoskonałości zarządzania na poziomie regionalnym i lokalnym. Wynikiem takiej polityki jest doprowadzenie do dysproporcji w rozwoju regionalnym oraz zaostrzenie procesów dezintegracji w państwie.

W warunkach ukraińskich jest szczególnie ważne by kontynuować wysiłki na rzecz reformy administracyjno-terytorialnej, rezygnując z nadmiernej centralizacji i swoistej dwuwładzy na poziomie regionalnym. Kolejnych problemów można uniknąc tylko przez budowę transparentnego systemu zarządzania, w którym regionom będą stworzone wszystkie warunki - w tym finansowe - do samoorganizacji i samorozwoju ${ }^{6}$.

Podstawą polityki regionalnej Ukrainy w obecnych warunkach ekonomicznych i z ograniczeniami budżetowymi musi być kombinacja pojedynczych zasad i norm zaczerpniętych z doświadczeń państw UE i implementacja ich do własnego scenariusza rozwoju. Dlatego też, zwłaszcza w oparciu o doświadczenia Polski, nale-

${ }^{5}$ А. Чиркін, Окремі питання реформування територіальної організацї публічнӧ влади в Республічі Польща, Актуамьні проблеми права: теорія і практика 2013, nr 27, s. 570.

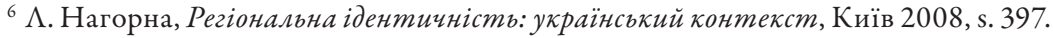


ży opracować te zasady, które staną się kluczowymi w tworzeniu i realizacji polityki regionalnej w Ukrainie.

Analizując praktykę realizacji polityki regionalnej w Ukrainie i w Polsce można wykazać pewne prawidłowości jej wpływu na rozwój systemu politycznego. Przede wszystkim, polityka regionalna powinna mieć solidną podstawę prawną. Jeśli spojrzeć na polski system prawny i treść dokumentów strategicznych dla rozwoju regionalnego, widzimy sytuację, w której nie istnieje jasne i spójne zdefiniowanie polityki regionalnej. Mimo to podstawowe akty normatywne jasno określają strukturę instytucjonalną tej polityki, uprawnienia na poziomie centralnym i regionalnym, tworzą instrumenty jej realizacji i sposoby pozyskania i wykorzystania funduszy unijnych.

W Ukrainie natomiast obserwuje się niską efektywność realizacji oraz znaczące przeciąganie procedur wypracowania i wdrażania aktów normatywno-prawnych, mających na celu zabezpieczenie i przyspieszenie krajowego rozwoju regionalnego. Pozytywnym przykładem może być opracowanie koncepcji reformowania samorządów miejscowych oraz przyjęcie ustawy $O$ zasadach państwowej polityki regional$n e j$. Pozwala to na stworzenie niezbędnych warunków dla dynamicznego i zrównoważonego rozwoju ukraińskich regionów, eliminację podstawowych dysproporcji oraz powrót do idei realnego samorządu.

Ważnym elementem reorganizacji polityki regionalnej jest opracowanie skutecznej instytucjonalnej struktury polityki regionalnej. Na obecnym etapie rozwoju regionalnego Ukrainy zaobserwować można rozproszenie na poziomie centralnym. Problematyką tę podejmują co najmniej trzy resorty - Ministerstwo rozwoju gospodarczego i handlu Ukrainy, Ministerstwo rozwoju regionalnego, budownictwa i gospodarki mieszkaniowo-komunalnej Ukrainy oraz Ministerstwo Finansów Ukrainy.

$\mathrm{Na}$ poziomie regionalnym obserwowalny jest nieracjonalny oraz niejasny podział pełnomocnictw między władzami lokalnymi i organami władzy wykonawczej, zawartych w obowiązujących przepisach. Dostrzegalne jest także upolitycznienie samorządów lokalnych oraz brak w rejonowych oraz obwodowych samorządach możliwości samodzielnego wdrażania lokalnej polityki z powodu braku prawa tworzenia komitetów wykonawczych?

Aby potwierdzić prezentowane trendy można wskazać wyniki monitoringu sieci społecznej OPORA na temat działalności lokalnych samorządów oraz otwartości i przejrzystości w polityce municypalnej. Badanie zostało przeprowadzone w 15

\footnotetext{
${ }^{7}$ М. Аацишин, В. Керецман, Інститущійне забезпечення регіональної політики та практика взаємодії органів влади в Україні, Київ 2007, s. 53.
} 
gminach i zawiera: wywiady eksperckie, prowadzone na początku kampanii wyborczej; analizy wyników działalności nowo wybranych władz w ciągu 100 dni; obserwacje pracy posłów podczas sesji Rady w ciągu pół roku; publikacje projektów decyzji itp. Ciekawe okazały się wyniki analizy składu deputowanych. W większości gmin do $70 \%$ posłów to przedstawiciele biznesu, kierownicy zakładów państwowych, prywatnych, komunalnych. Tendencja ta stwarza warunki do lobbingu indywidualnych interesów gospodarczych przez stronniczych posłów oraz zwiększenia poziomu zagrożenia korupcją w działalności deputowanych ${ }^{8}$.

Wskazane więc jest, aby wykorzystać polską próbę połączenia zasady decentralizacji i regionalizacji z zasadami państwa unitarnego. Organy samorządu przyjęły odpowiedzialność za ustalanie celów polityki regionalnej, ich realizację oraz wyniki. Ze swojej strony rząd jest odpowiedzialny za określenie ogólnych celów rozwoju regionalnego, sprecyzowanie działalności samorządów, wyrównywanie dysproporcji między regionami. Reforma w Polsce opierała się na wcześniejszych doświadczeniach. W większości regionów miała ona charakter ewolucyjny i była konsekwencją działań, które rozpoczęły się dość dawno temu. Przeprowadzanie reformy odbywało się w dwóch etapach: politycznym, związanym z tworzeniem warunków instytucjonalnych demokratyzacji tej sfery i administracyjnym, mającym na celu restrukturyzację jej elementów konstrukcyjnych ${ }^{9}$.

Innym ważnym elementem reformowania jest długoterminowość polityki regionalnej, wymaga ona bowiem strategicznej wizji celów, które należy osiągnąć. Jednym z najważniejszych kierunków polityki regionalnej jest więc opracowanie strategii rozwoju poszczególnych obwodów, miast i rejonów.

W ukraińskich realiach istnieje duża liczba celowych programów państwowych, które nie zostały zrealizowane głównie przez brak wsparcia finansowego. Obecny rząd natomiast przygotowuje nowe plany. Podobna sytuacja występuje w regionach. Liczne, wypracowane tam programy nie spełniają wymogów ustawy Ukrainy $O$ państwowych programach docelowych i pozostają wyłącznie na papierze $^{10}$.

${ }^{8}$ ОПОРА оцінила особливості роботи місцевого самоврядування у 15 регіонах, http://ороraua.org/news/1156-100-dniv-dijalnosti-chy-bezdijalnosti-miskyh-rad-rezultaty-gromadskogomonitoryngu-v-15-mistah-ukrajiny, odczyt z 11.10.2011.

${ }^{9}$ Н. Шаповалова, І. Пресняков, Адміністративна реформа у Польщі: напрямки змін та реальні результати, Аіалог 2005, http://dialogs.org.ua/ru/cross/page3636.html, odczyt z 15.06.2005.

${ }^{10}$ Національні Стратегї регіонального розвитку Республіки Польщі та Украйни: порівняльнийаналіз транспортнихаспектів, 2008, nr 2, http://old.niss.gov.ua/monitor/September/13. htm, odczyt z 22.09.2007. 
Jeśli chodzi o polskie doświadczenia to nie ograniczyły się one wyłącznie do zatwierdzenia Strategii Rozwoju Regionalnego. Powstało wiele spójnych strategicznych dokumentów, w których widać konsekwencję, przejrzystość oraz prezentację poszczególnych kroków wykonawców całego pionu władzy, włącznie z zatwierdzeniem szacunków każdego projektu.

Potrzeba uproszczenia zarządzania, zmniejszenie liczby programów rozwoju sprzyjały działaniom mającym na celu opracowanie zintegrowanych strategii rozwoju, co pomogło stworzyć skuteczny system. Polski rząd jeszcze w 2009 roku rozpoczął reformę zarządzania programowego. Utworzono trzy poziomy: Długoterminową strategię rozwoju - Polska 2030 (przygotowaną przez doradcę premiera, posiada jasno określone wskaźniki celów i wyników); Średnioterminową strategię rozwoju Polski do roku 2020 (w celu ułatwienia długoterminowego myślenia i przygotowania do debaty budżetowej w UE na lata 2014-2020); oraz dziewięć zintegrowanych strategii (Komitet Koordynacyjny) ${ }^{11}$.

W Polsce dokumenty strategiczne są przedmiotem szerokich debat publicznych i dyskusji, które odbywają się z udziałem rządu RP i zainteresowanych stron w ciągu kilku miesięcy. W Ukrainie zazwyczaj ogranicza się do dyskusji na temat projektów gotowych dokumentów na rozszerzonych kolegiach ministerialnych. Wyjątki stanowią otwarte debaty publiczne.

Należy zwrócić uwagę, że istnienie niezależnych od politycznej koniunktury regionalnych dokumentów strategicznych, których realizacja jest stale monitorowana oraz istnienie tylko jednej odpowiedzialnej za ich wykonanie instytucji jest ważnym argumentem dla inwestorów gospodarczych.

Dzięki wprowadzeniu efektywnego planowania strategicznego na szczeblu regionalnym, miejscowe samorządy powinny przekształcić się z organów, które reagują na wydarzenia w Ukrainie i za granicą, w organy, które mają długoterminową wizję swoich celów i sposobów ich realizacji. Dzięki temu istnieje szansa uniknięcia ewentualnych przeszkód i systematyczne wdrażanie planów z uwzględnieniem rzeczywistych możliwości finansowych. Interesy strategiczne regionu muszą być zgodne z prawem, co wymaga obowiązkowego uzgodnienia interesów państwowych z kierunkiem rozwoju regionalnego. Aspekt ten warunkuje efektywność omawianych strategii ${ }^{12}$.

Równie ważnym celem strategii rozwoju regionalnego jest uwzględnienie interesów wszystkich politycznych, ekonomicznych i społecznych grup, niezależnie

\footnotetext{
${ }^{11}$ Реформа стратегічного управління в Польщі (2009-2012), http://www.groupua.org/?p= 2085, odczyt z 7.03.2012.

${ }^{12}$ О. Коврига, Особливості інституційних процесів в Украӥні на регіональному рівні, Аержавне будівництво 2008, nr 2, http: //www.kbuapa.kharkov.ua, odczyt z 20.03.2014.
} 
od ich wpływów i pozycji oraz ewentualnych przetasowań wyborczych. Wszystko to wymaga stworzenia skutecznych mechanizmów współpracy między podmiotami polityki regionalnej. Jednym z takich mechanizmów jest powołanie np. grup roboczych do spraw planowania rozwoju regionalnego.

Odpowiednia realizacja etapów rozwoju regionalnego pozwoli państwom kandydującym i członkom UE na uzyskanie dostępu do pomocy finansowej. Polska od 1990 roku była aktywnym beneficjentem funduszy przedakcesyjnych, które umożliwiły modernizowanie infrastruktury, energetyki i wsparcie reform. Jednak największe korzyści Polska uzyskała dopiero jako członek UE. Najważniejsze to dotacje bezpośrednie z budżetu UE, przyznawane w ramach realizacji priorytetowej polityki wyrównywania i wsparcia dla rolnictwa. W sumie od momentu przystąpienia do UE (1 maja 2004 r.) Polska otrzymała prawie 85,3 miliardów euro ${ }^{13}$.

Należy podkreślić, że powyższe kwoty trafiają do budżetu i przeznaczane są na finansowanie kierunków programów operacyjnych. Przy czym większość środków - są to wydatki kapitałowe, które nie mogą być wykorzystane w innych celach. Znaczna ilość środków UE przeznaczana jest na unowocześnienie infrastruktury, realizację działań w zakresie efektywności energetycznej, rozwój małych przedsiębiorstw, finansowanie edukacji i nauki itp.

Tymczasem jeszcze niedawno strategia UE w kwestii programów grantowych dla Ukrainy opierała się o zasadę: najpierw projekty miękkie dla wsparcia społeczeństwa obywatelskiego (konferencje, stypendia, wizyty studyjne), a dopiero potem - twarda pomoc. Na ile ta polityka była skuteczna? Ukraina jest nadal w tzw. szarej strefie i pozostaje w grupie najbardziej skorumpowanych państw świata. Projekty grantowe z UE i USA nie zmieniły radykalnie tej sytuacji ${ }^{14}$.

Ponadto Ukraina ma typową scentralizowaną dystrybucję zasobów finansowych, które są skierowywane na rozwój konkretnych terytoriów; finansowa niesamodzielność generuje także inne rodzaje zależności od centrali. Wydaje się, że wprowadzając w życie własne programy rozwoju regionalnego władze lokalne powinny samodzielnie zarządzać zasobami finansowymi, gwarantowanymi stabilnymi źródłami dochodów.

Wraz z rozpoczęciem reformy polityki regionalnej, Ukraina - jak twierdził komisarz ds. rozszerzenia i europejskiej polityki sąsiedztwa Štefan Füle - otrzyma możliwość uzyskania $55 \mathrm{mln}$ euro, które zostaną skierowane na finansowanie rozwoju regionalnego: projekty infrastrukturalne i humanitarne. Konsekwentne

${ }^{13}$ Iнтеграція до ЄС: досвід Польщі та виклики для України, http://gazeta.dt.ua/macrolevel/ integraciya-do-yes-dosvid-polschi-ta-vikliki-dlya-ukrayini-_.html, odczyt z 27.09.2013.

${ }_{14}$ Нова РHARE для модернізачіï України, http://gazeta.dt.ua/international/nova-phare-dlyamodernizaciyi-ukrayini-_.html, odczyt z 21.03.2014. 
podjęcie tych działań może się okazać ważnym krokiem do pozyskiwania środków europejskich ${ }^{15}$.

Wyniki realizacji polityki regionalnej, w pierwszej kolejności, muszą być udostępnione opinii publicznej i ekspertom. Bez społecznego poparcia wszelkie działania, nieuchronnie będą kwestionowane, a nawet dyskredytowane. Akceptacja jest niezbędnym warunkiem sukcesu tej polityki. Polska w tym kontekście zapewniła udział zainteresowanych stron w procesie przejmowania odpowiedzialności władz na szczeblu wojewódzkim, co jest określone w ustawie o zasadach wspierania rozwoju regionalnego ${ }^{16}$.

Ponadto, oprócz władz centralnych i lokalnych ważne jest, aby włączać niezależne, społeczne instytucje (agencje rozwoju regionalnego, centra wspierania małego biznesu, centra zasobów oraz informacji, inkubatory przedsiębiorczości, centra transferu wiedzy naukowej i technicznej itp).

Według Departamentu strategii zarządzania rozwoju regionalnego, dla pomyślnego wsparcia instytucjonalnego państwowej polityki regionalnej wskazane jest zdefiniowanie mechanizmów współpracy stowarzyszeń (szczególnie Stowarzyszenia agencji rozwoju regionalnego Ukrainy) z władzami państwowymi w procesie opracowania i wdrażania państwowej polityki regionalnej oraz rozpoczęcie działań takich instytucji finansowych jak Narodowy ukraiński fundusz rozwoju regionalnego i funduszy regionalnych. Regulacji prawnej (z uwzględnieniem doświadczenia funkcjonowania funduszy strukturalnych UE) potrzebują aspekty pozyskiwania źródeł i określenia kluczowych kierunków wsparcia finansowego dla regionalnych projektów inwestycyjnych ${ }^{17}$.

W oparciu o reformy w Polsce, stworzone na szczeblu regionalnym agencje rozwoju powinny pełnić podwójną funkcję: opracowywać projekty strategii rozwoju regionu (wykorzystując dane z monitoringu regionalnego, własnych prac analitycznych) oraz - po zatwierdzeniu takich strategii - koordynować ich realizację, zapewniając przy tym różnorodną pomoc zainteresowanym stronom.

Kwestią czasu jest powstanie problemu skutecznej współpracy międzyregionalnej. Jednym z najbardziej efektywnych kierunków polityki regionalnej Ukrainy

\footnotetext{
${ }^{15}$ Міністерство регіонального розвитку, будівництва та житлово-комунального господарства України, http://minregion.gov.ua/, odczyt z 19.04.2014.

${ }^{16}$ Ustawa o zasadach wspierania rozwoju regionalnego z dnia 12 maja 2000 r., Dz.U. 1998, nr 48, poz. 550 .

${ }^{17}$ С. Біка, Перспективи залучення інвестиційних ресурсів структурних фондів ЄС в $У_{\kappa-}$ раїну (регіональний вимір), [w:] Проблемы развития внешнеэкономических связей и привлечения иностранныцх инвестищий: региональный аспект, Сборник научных трудов, Аонецк 2010, s. $10-18$.
} 
jest zachęcenie do wewnętrznego rozwoju regionów przez wykorzystywanie lokalnych warunków i zasobów oraz przewagi konkurencyjnej. W warunkach zglobalizowanej gospodarki światowej, nasilonego wpływu organizacji międzynarodowych i korporacji transnarodowych, państwo powinno współpracować z regionami jak z równymi partnerami. W efekcie przyniesie to wzrost gospodarczy i poprawę standardów życia. Oznacza to, że polityka regionalna powinna być zorientowana na rynek. Stwarzając warunki, w których relacje rynkowe rozwijają się najefektywniej, polityka regionalna przyczynia się do rozwiązywania palących problemów w najbardziej skuteczny sposób ${ }^{18}$.

Ponadto, w celu uzyskania pełnej funkcjonalności we współpracy międzyregionalnej, musi się odbyć przejście od handlowego do projektowego modelu relacji regionów. Chodzi tu o przygotowanie i realizację na poziomie międzyregionalnym projektów i programów, które zapewnią wspólny udział w wykorzystaniu potencjału zasobów regionów i osiągnięciu na tej podstawie efektu zrównoważonego rozwoju (głównie dzięki wzrostowi konkurencyjności). Rozwój współpracy międzyregionalnej powinien być skierowany na optymalizację wykorzystania istniejących w regionach zasobów, zwiększenie pojemności rynku wewnętrznego, tworzenie nowych miejsc pracy i rozwiązywanie wspólnych problemów regionalnych. Współpraca międzyregionalna w sferze gospodarczej jest możliwa przez realizację istniejących umów, przeznaczenie odpowiednich środków finansowych oraz wspólne działania w ramach projektów narodowych ${ }^{19}$.

Radykalnej przebudowy wymaga również krajowy system wsparcia statystycznego państwowej polityki regionalnej - dziśs właściwie nieobecny w Ukrainie. Brak jest ogólnokrajowej informacji statystycznej na poziomie subregionalnym. Konieczne jest więc - zgodnie z przepisami Unii Europejskiej - stosowanie ujednoliconej metodologii statystycznej. Należy opracować standardy Nomenklatury Jednostek terytorialnych do celów statystycznych (lub ujednoliconego systemu klasyfikacji NUTS - Nomenclature of Territorial Units for Statistical Purposes) na podstawie standardów UE i z uwzględnieniem narodowej specyfiki podziału terytoriów na rejony. Chodzi o to, aby spełniały one wymagania UE NUTS-3, natomiast regiony - NUTS-2. Wymaga to wdrożenia reformy administracyjno-terytorialnej ${ }^{20}$.

${ }^{18}$ В. Бабаєв, Сучасні політичні практики краӥн Європи: досвід для формування регіональної політики в Україні, Аержавне будівництво. Світовий досвід Аержавного управління: теорія та практика 2007, nr 1, s. 14-15.

${ }^{19}$ С. Біка, Регіони України у післякризовий період: ризики та перспективи розвитку, Київ 2011, s. 35-36

${ }^{20}$ Eadem, Держава та регіони: від патерналізму до партнерства, Київ 2010, s. 54. 
Według opinii ekspertów, przeprowadzenie reformy administracyjno-terytorialnej w Ukrainie, wzorowanej na polskim modelu, znacznie zmniejszy różnice międzyregionalne, doprowadzi do ustalenia tzw. odpowiedzialnego regionalizmu, który przewiduje efektywny rozwój każdego regionu oraz państwa jako całości. Idealizowanie polskich reform (koncentracja wyłącznie na jej pozytywnych cechach) niesie jednak niebezpieczeństwo powtórzenia błędów popełnionych przez rząd polski, oraz zaniedbań w dostosowaniu polskich przepisów do ukraińskich realiów.

Podsumowując, należy pamiętać, że polityka regionalna powinna mieć na celu zmniejszenie dysproporcji przestrzennych, które powstały w wyniku zmian systemu administracyjnego, a obecnie pogłębiają się, prowokując nastroje separatystyczne. Powinna także wzmacniać procesy transformacyjne na poziomie regionu, uwzględniając jego szczególne położenie geopolityczne, zasoby naturalne i cechy ekonomiczne, w celu wyeliminowania systemowych, cyklicznych i strukturalnych problemów w skali krajowej.

Ukraina, jako jedno z największych pod względem terytorium i ludności państw Europy, nie może być efektywnie zarządzana w sposób centralny. Skuteczne rządzenie powinno zostawiać więcej przestrzeni politycznej dla poszczególnych regionów, dając im więcej swobody. Istotnym celem reformy władz regionalnych jest więc powołanie politycznie sprawnych osób, posiadających demokratyczną legitymację oraz stworzenie im przestrzeni do współpracy z wszystkimi szczeblami zarządzania w państwie.

W nowych warunkach rozwoju Ukrainy fundamentem polityki regionalnej państwa powinny stać się strategia partnerstwa, integracji wewnętrznej i zewnętrznej, przejście do polityki odpowiedzialnej regionalizacji. Powinna on obejmować nie tylko rozszerzenie funkcji i przekazanie pełnomocnictw, ale także stworzenie narzędzi odpowiedzialności władz lokalnych przed społeczeństwem oraz sobą nawzajem. Samorządy powinny wziąć wspólną odpowiedzialność za rozwój społeczny i gospodarczy kraju, zwłaszcza w czasie wyjścia z globalnego kryzysu finansowego i gospodarczego.

Także podczas redystrybucji dochodu narodowego priorytetem powinno być stymulowanie inicjatywy oddolnej oraz skuteczne wykorzystywanie potencjału regionów. Przez zwiększenie lokalnej aktywności regiony mają możliwość osiągnięcia najbardziej korzystnej struktury i specjalizacji gospodarki. Pełnowartościowa demokracja jest niemożliwa i nieosiągalna bez integracji społeczeństwa z władzą. 